\title{
Performance Analysis of UPF Rectifier-Fed Induction Motor Drive
}

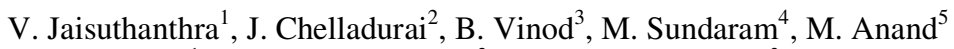 \\ \{vjaisuthanthra@gmail.com ${ }^{1}$, jcd.eee@psgtech.ac.in ${ }^{2}$, hod.rae@psgtech.ac.in ${ }^{3}$, msm.eee@psgtech.ac.in ${ }^{4}$, \\ and.eee@psgtech.ac.in ${ }^{5}$ \\ ${ }^{1}$ PG Scholar, ${ }^{2,5}$ Assistant Professor, ${ }^{3}$ Professor, ${ }^{4}$ Associate Professor, EEE Dept. PSG College of \\ Technology, Coimbatore, India 641004
}

\begin{abstract}
This paper presents the source current wave shaping of variable frequency induction motor drive system using Unity Power Factor (UPF) rectifiers. Rectifier fed induction motors are the essential part in industrial applications because it is difficult to convert the input supply frequency directly for variable frequency drive. Hence, it is necessary to connect the AC/DC converterfollowed by DC/AC converter system to vary the input supply frequency and magnitude of the motor. The conventional rectifier draws a non-linear current and injects harmonics into the power system network. The two different UPF rectifier models are proposed here for controlling the amount of harmonics injected into the AC power system to increase the input power factor. The proposed UPF rectifier-fed induction motor drive systems reduce the source current THD and maintains the DC-link voltage as constant. The performance of Vienna rectifier, PWM rectifier systems are compared with a conventional three phase bridge rectifier-fed Induction motor drive.
\end{abstract}

Keywords: Induction Motor, Vienna Rectifier, Inverter, Total Harmonic Distortion, Power Factor, Electric Drives

\section{Introduction}

In modern drives, the demand is for precise and continuous control of speed and torque with high efficiency and good transient performance. AC drives have proven technically and economically attractive for industrial applications. AC drive has lower inertia, higher efficiency due to the absence of commutator and brushes. It can operate directly from ac supply for constant speed and constant frequency. In variable speed and frequency applications, it is predicted that ac drives especially induction motor will replace dc drives. For VFD we need ac to dc converter because it is difficult to convert the input supply frequency directly. The conventional rectifier draws anon-linear current and hence reduces the input power factor [1-3]. The UPF Vienna rectifier is proposed due to its numerous advantages. It converts the AC input to DC with low harmonic current injection in AC side with UPF operation. The boost inductor used in Vienna rectifier topology is used to increase the DC link voltage magnitude and also it improves the source side current wave shape [4,5]. This unidirectional topology controls the DC voltage across the capacitor and the amount of current THD in AC input. These advantages are achieved by voltage and current control technique [6]. The hysteresis current controller works by comparing the reference and mains current signal. Under variable frequency mode of operation, the UPF Vienna rectifier model is controlled using hysteresis current control method to improve the input power factor [7]. Input AC side and DC-link side passive filters based electric drives configuration offers very less power factor, less harmonic reduction and poor dynamic performance. The DC passive capacitive filters used in such configuration increases the amount of harmonic current in 
source side. The proposed active filters based drive topology offers a good dynamic performance and improves the power quality [8-10].

A three-phase $10 \mathrm{hp}, 400 \mathrm{~V}, 50 \mathrm{~Hz}$ asynchronous machine is considered as a load to compare the proposed UPF rectifier topologies. In terms of input source current THD the conventional diode bridge rectifier based fed induction motor drive system is compared with the proposed system.

\section{Modelling of Vienna Rectifier}

There are number of control methods used for controlling the Vienna rectifier. In this paper, the Vienna rectifier model is controlled using variable frequency hysteresis current control technique. The Hysteresis Current Controller (HCC) reduces the implementation cost and provides fast dynamic response. It works by comparing the reference and mains current signal. The Vienna rectifier power switches are controlled by gate pulses generated using hysteresis current control technique, offers a UPF operation with less harmonic current injection and good dynamic performance [11-13].

Figure 1depicts the power circuit diagram of the Vienna rectifier. The maximum three phase voltage is given as an input to the Vienna rectifier and a boost inductor is added at the source side to reduce the source current wave shape. Then the system consists of 18 diodes, 3 MOSFET switches and two capacitors. Here, two capacitors are connected as a midpoint and it is used to reduce the DC ripple voltage.

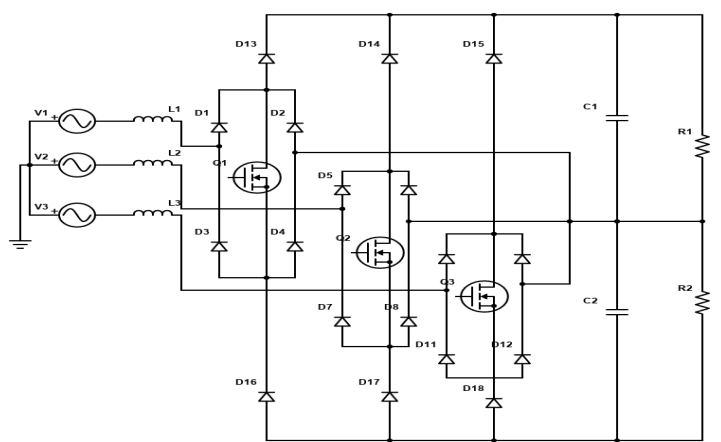

Fig. 1 Power Circuit Diagram of the Proposed Vienna Rectifier

The voltage equation of the Vienna rectifier can be expressed as:

$\mathrm{V}_{1}=\mathrm{V} \sin \left(\mathrm{w}_{\mathrm{s}} \mathrm{t}\right)$

$V_{2}=V \sin \left(w_{s} t+120\right)$

$\mathrm{V}_{3}=V \sin \left(\mathrm{w}_{\mathrm{s}} \mathrm{t}-120\right)$

whereV $V_{1}, V_{2}$ and $V_{3}$ are three phase voltages of the Vienna rectifier. $V_{m}$ is the maximum value of the source voltage. The angular frequency of the voltages is represented as $\mathrm{w}_{\mathrm{S}}[14]$.

The hysteresis current control is simple and easy to be implemented and it is widely used in inverters, rectifier applications. The operation of this vienna rectifier controller is to compare the measured output current of the system with the reference current. The error of measured current in the system is controlled by fixed hysteresis bandwidth with two levels of control. This controller generates pulse for switching the power semiconductor switches [13]. 


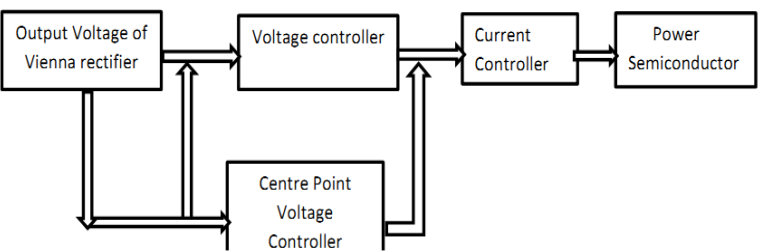

Fig.2 Block Representation of Hysteresis Current Controller

Figure 2 shows the block representation of hysteresis current controller. The Hysteresis current control technique is applied in three different subsystems which are shown in Fig. 2. Each controller has their own subsystem with controller.The output of the voltage controller is processed through the current controller to control the power semiconductor switches.

There are different methods for designing PI controller. They are Ziegler-Nichols method, frequency response, pole-placement method etc.[13].

The transfer function of PI controller can be expressed as

$$
\operatorname{PI}(\mathrm{s})=\mathrm{K}_{\mathrm{p}}+\frac{\mathrm{K}_{\mathrm{s}}}{\mathrm{s}}
$$

where,

$\frac{\mathrm{K}_{\mathrm{s}}}{\mathrm{s}}=$ Integral constant and $\mathrm{K}_{\mathrm{p}}=$ Proportional constant

The trial and error method is used for tuning the PI controller in voltage controller and current controller block. The Kp value is first increased to obtain desire output value. Then Ki value is adjusted until the system achieves steady state [13].

At running time, the HCC generates the gate signals for the three MOSFET switches.The capacitor voltages are added and processed through the voltage controller, which is regulated through PI controller in this system. The required gate pulses are generated by using the current reference signal processed through the hysteresis current controller.

\section{Modelling of Voltage Oriented PWM Boost Rectifier}

The boost three-phase power factor correction rectifier is an alternate system to improve the system current performance and source side power factor. As per IEEE 519 standard the maximum allowable harmonic current magnitude at the point of common coupling is less than 5\%. The boost PWM rectifier offers a good dynamic performance with very less amount of harmonic current injection [14-16]. The advantages of PWM Boost rectifier are as follows.

- $\quad$ The current flow can be reversed

- Constant DC link voltage magnitude 


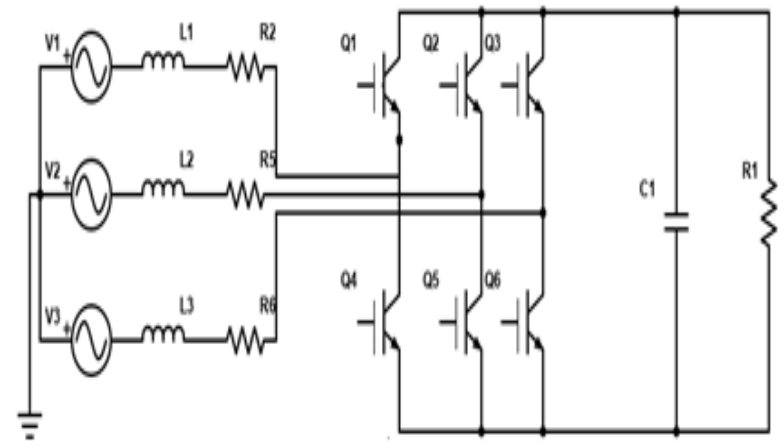

Fig. 3 Power Circuit Diagram of PWM Boost Rectifier

Figure 3 shows the power circuit diagram of Boost PWM rectifier. The balanced three phase voltage is given as input to the six pulse PWM Boost rectifier. The output DC voltage $600-700 \mathrm{~V}$ was achieved. The resulted output voltage of this rectifier is given to the inverter. The inverter converts it into $400 \mathrm{~V}$ and then it is injected to the stator of the induction motor.

\section{Results and Discussion:}

In this paper three different front end converter configurations are considered to compare the source side current performance of induction motor drive system. The proposed systems are as follows

- $\quad$ Conventional AC drive system.

- Vienna rectifier fed AC drive system.

- $\quad$ PWM Boost Rectifier fed AC drive system.

In the boost PWM technique the closed loop control algorithm is implemented using voltage oriented control. The required voltage reference angle of the system is derived from PLL. This voltage angle is then used for all the dq-transformations in the circuit [9].

From abc to $\alpha \beta$ transformation of voltage:

$$
\left[\begin{array}{l}
V_{\alpha} \\
V_{\beta}
\end{array}\right]=\sqrt{\frac{2}{3}}\left[\begin{array}{ccc}
1 & -\frac{1}{2} & -\frac{1}{2} \\
& \frac{\sqrt{3}}{2} & -\frac{\sqrt{3}}{2}
\end{array}\right]\left[\begin{array}{l}
V_{1} \\
V_{2} \\
V_{3}
\end{array}\right]
$$

The voltage matrix value of $\alpha \beta$ in equation 4.1.is applied to PLL.The voltage matrix value of $\alpha \beta$ in equation 4.1.is applied to PLL.

Figure 4 shows the Simulink block representation of PLL. The output theta angle is given as an input to the abc to dq transformation block. The processed dq transformation data is finally converted into abc to generate the PWM pulses. 


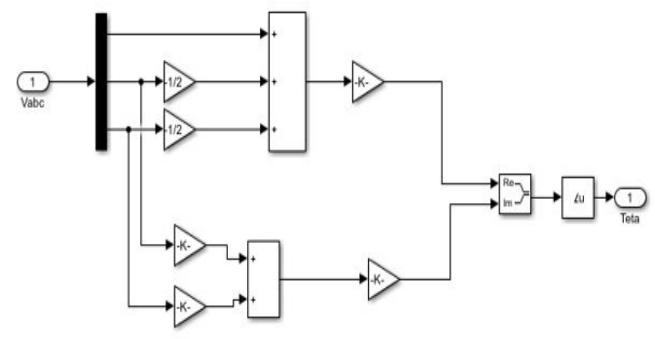

Fig.4 Simulink Block Representation of PLL

\section{Analysis of conventional AC drive system}

A 10 HP induction motor model is considered as a load. The motor is controlled using an inverter with three different front end converters. For the given load the required boost inductor, DC-link inductor and capacitor values are calculated and is tabulated in Table 5.1 .

\begin{tabular}{|l|c|}
\hline Description & Values \\
\hline AC Phase Voltage (Vrms) & $230 \mathrm{~V}$ \\
\hline Main Frequency & $50 \mathrm{~Hz}$ \\
\hline Source side Boost Inductor & $0.3 \mathrm{mH}$ \\
\hline Rectifier output capacitor & $3000 \mu \mathrm{F}$ \\
\hline Rectifier output inductor & $3.2 \mathrm{mH}$ \\
\hline Motor Power Output & $10 \mathrm{HP}$ \\
\hline capacitor Voltage & $700 \mathrm{~V}$ \\
\hline converterpower switch Frequency & $5 \mathrm{kHz}$ \\
\hline
\end{tabular}

Table 1 System Specifications

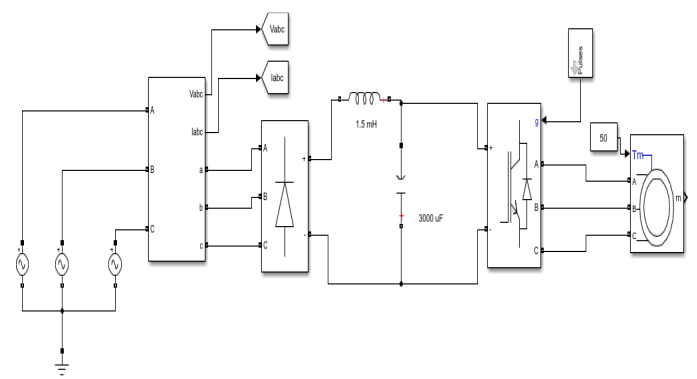

Fig. 5 Simulink Schematic Diagram of Conventional AC Drive System

Figure 5 shows the simulink schematic diagram of the conventional induction motor speed control system with DC-link inductor and capacitor. In order to compare the amount of harmonic current injected into the system the proposed front end converters; theconventional 
diode bridge rectifier based motor drive system is simulated using MATLAB/Simulink. The DC side inductor and capacitor reduces the amount of input current harmonics and maintains constant DC voltage respectively.

Figure 6 shows output voltage waveform of three-phase DBR with DC link Capacitor $\&$ Inductor for $10 \mathrm{HP}$ motor load. It infers that the output voltage contains less ripples due to the combination of L\&C but the maximum possible DC side voltage is only $537 \mathrm{~V}$. The resulted DC output voltage is given to the inverter. By changing the modulation index, the inverter produces output voltage of $400 \mathrm{~V}$ and then it is injected to the stator of the $10 \mathrm{HP}$ induction motor. Finally, the different load torque is applied to $10 \mathrm{HP}$ induction motor and the corresponding current THD value is calculated. The obtained current THD value is $39.55 \%$ for $100 \%$ load torque, $69.98 \%$ for $75 \%$ load torque, $114.89 \%$ for $50 \%$ load torque and $141.19 \%$ for $25 \%$ load torque. All these values are tabulated in Table 2.

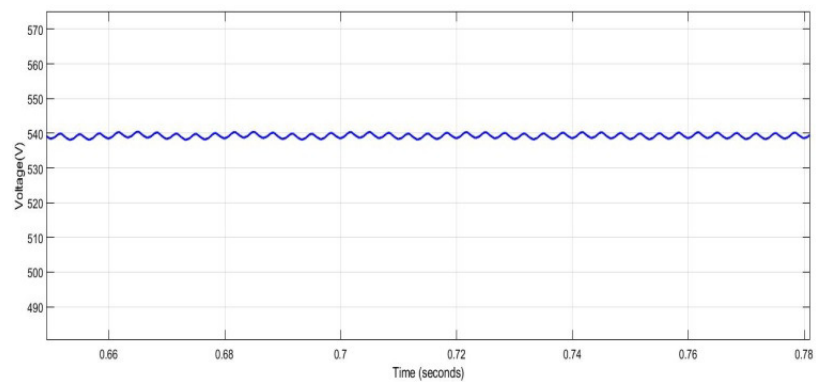

Fig. 6 DC-link Voltage Waveform ofThree-Phase DBR Fed Variable Frequency Drive System

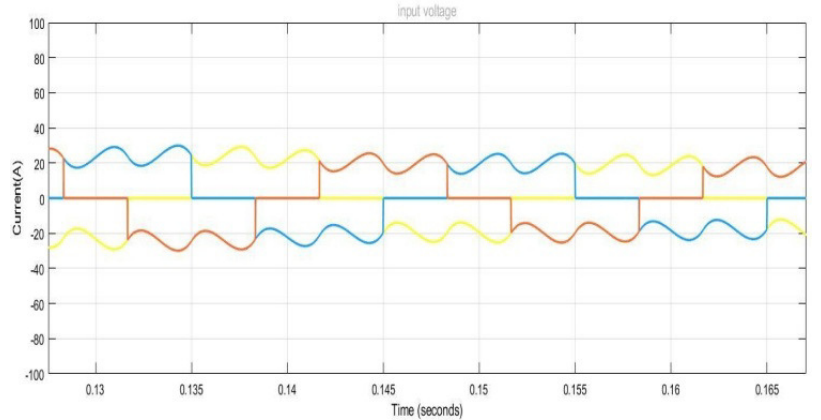

Fig. 7 Three Phase Source Current Waveform of DBR Fed AC Drive System

Figure 7 shows the three-phase source current waveform of conventional AC drive system and it could observe that the shape of the input current gets distorted. So, to overcome this problem the high-power quality front end converter is needed. Figure 8 shows the 3 cycles of the input R-phase source current waveform and the corresponding wave harmonic spectrum. The fundamental RMS value of the R-phase input current is $18.18 \mathrm{~A}$, and the overall THD value obtained is $39.51 \%$. 


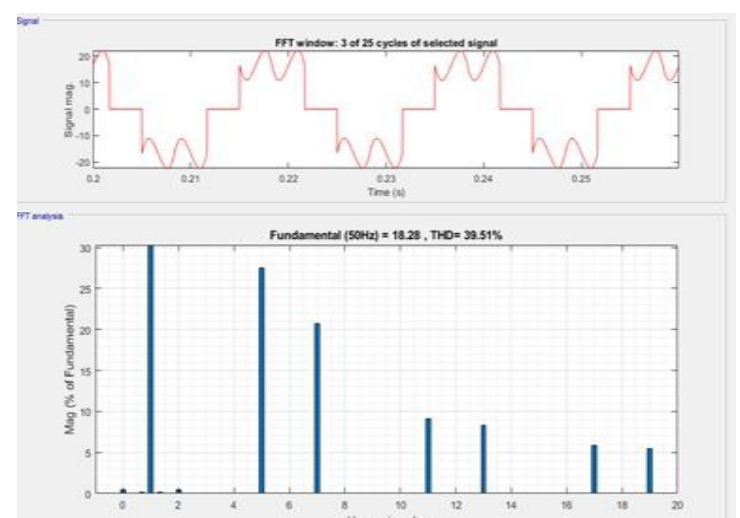

Fig. 8 R-Phase Source Current Waveform and Its Harmonic Spectrum of Conventional AC Drive System

\section{Analysis of Vienna rectifier fed AC drive system}

In the conventional drive system, the input current wave shape is purely non-linear one and hence the harmonics of the conventional drive system is also very high. The three phase AFE Vienna rectifier is a good replacement of diode bridge rectifier. In the proposed induction motor drive system, instead of using the bridge front end rectifier the Vienna rectifier power circuit is connected and analyzed under the same operating condition. Due to the presence of closed loop control of power devices in Vienna rectifier, the output DC voltage is more stable and has a limiting fluctuation. In the proposed configuration, the input boost inductor based FEC increases the dc-link voltage magnitude upto $700 \mathrm{~V}$, it is shown in Fig. 9.The resulted DC output voltage is given to the inverter. By changing the modulation index, the inverter produces output voltage of $400 \mathrm{~V}$ and then it is injected to the stator of the $10 \mathrm{HP}$ induction motor.

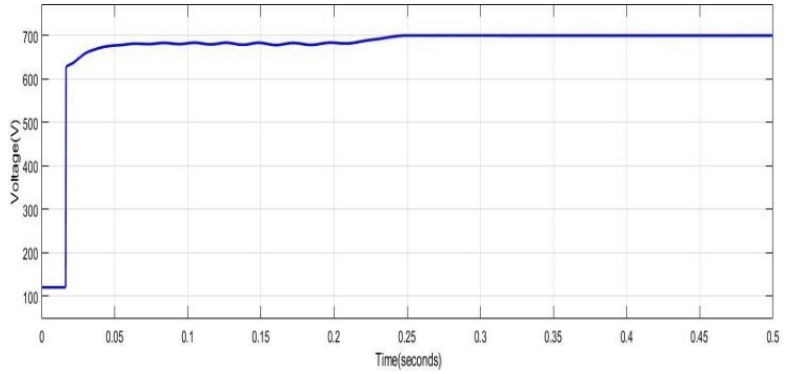

Fig. 9 DC-link Voltage Waveform of Vienna Rectifier Fed AC Drive System 


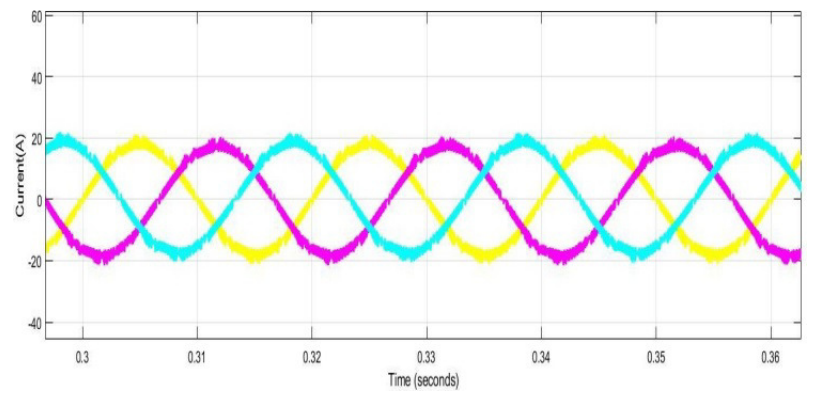

Fig. 10 Three Phase Source Current of Vienna Rectifier Fed AC Drive System

Figure 10 shows the input three-phase source current waveform of Vienna Rectifier fed AC drive system; it is observed that the input current wave shape is almost sinusoidal in nature.The R-phase current waveform and the corresponding harmonic spectrum are shown in Fig. 11. The fundamental value of the R-phase input current is $18.85 \mathrm{~A}$, and the THD value obtained is $7.61 \%$. It is absorbed that the overall THD value is very less compared to conventional drive system and the lower order harmonic content is also very less. The propose Vienna rectifier based system is analyzed under different load torque applied to $10 \mathrm{HP}$ induction motor and the corresponding current THD value are tabulated in Table 2. The obtained current THD value is $7.68 \%$ for $100 \%$ load torque, $7.55 \%$ for $75 \%$ load torque, $7.35 \%$ for $50 \%$ load torque and $7.42 \%$ for $25 \%$ load torque. It is absorbed that comparted to the conventional DBR based drive system, the Vienna rectifier based system under variable load condition the amount of injected harmonic currents are constant.

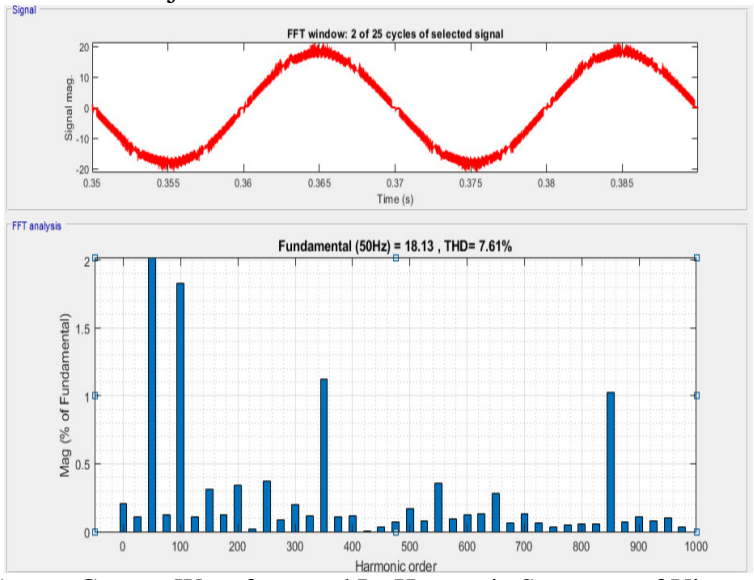

Fig. 11 R-Phase Source Current Waveform and Its Harmonic Spectrum of Vienna Rectifier Fed AC Drive System

\section{Analysis of PWM boost rectifier fed AC drive system}

To study the performance of the boost PWM rectifier based system, in the test system the front end converter is considered as boost PWM rectifier. The switching frequency of the proposed PWM Boost rectifier is considered as $5 \mathrm{kHz}$. In this topology the required AC side boost inductor is calculated as $0.3 \mathrm{mH}$. The PWM Boost rectifier fed AC drive system is compared with the other topologies. The closed loop control algorithm of boost PWM rectifier 
effectively maintains the DC side voltage magnitude as constant one which is shown in Fig. 12.Similar to that of the Vienna rectifier, in the proposed boost PWM rectifier configuration, the DC-link voltage magnitude is considered as $700 \mathrm{~V}$. The resulted DC output voltage is given to the inverter. In order to compare the PWM rectifier based system with other two configurations, the test system is analyzed under various load conditions. Under variable load conditions, the obtained current THD value is $3.44 \%$ for $100 \%$ load torque, $3.28 \%$ for $75 \%$ load torque, $3.32 \%$ for $50 \%$ load torque, $3.55 \%$ for $25 \%$ load torque which is tabulated in Table 2,Fig.13 shows the input current waveform of PWM Boost rectifier fed AC drive system and it could observe that the nearly sinusoidal input current is achieved. Comparing with Vienna rectifier topology, the input current harmonics have to be reduced further. So, the high-power quality AFE converter is achieved by using the OPWM rectifier. The input current harmonic spectrum of PWM Boost rectifier fed AC drive system shown in the Fig. 14. The fundamental value of the R-phase input current is $18.44 \mathrm{~A}$ and the THD value obtained is $3.44 \%$, which is well below the IEEE-519 standard.

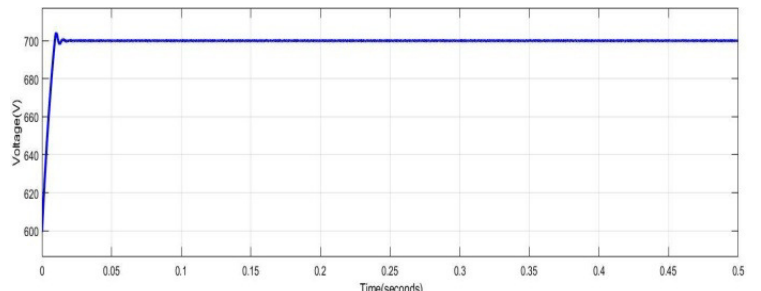

Fig. 12 DC-link Voltage Waveform of PWM Boost Rectifier Fed AC Drive System

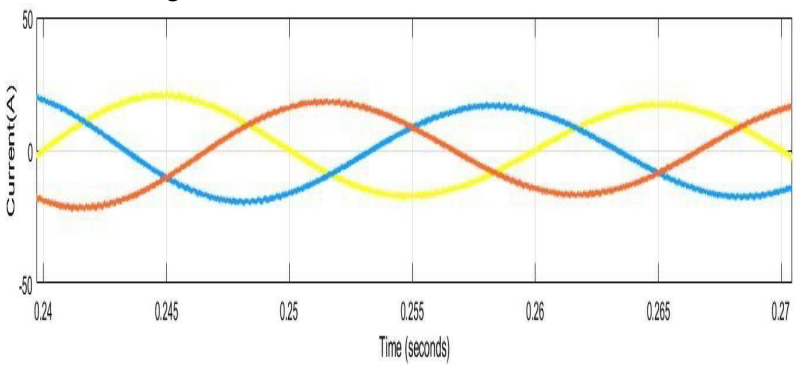

Fig. 13 Input Current Waveform of PWM Boost Rectifier Fed AC Drive System

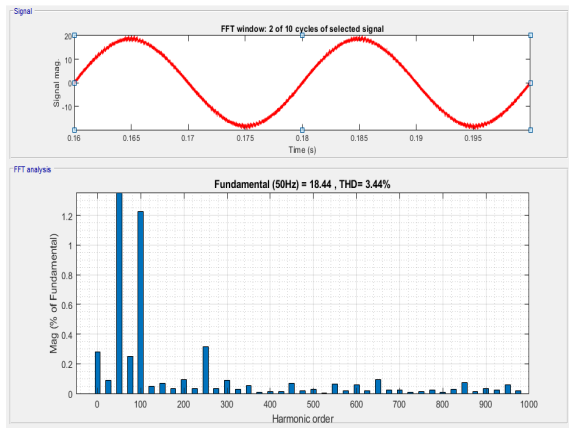

Fig. 14 R-Phase Source Current Waveform and Its Harmonic Spectrum of PWM Boost Rectifier Fed AC Drive System 


\begin{tabular}{|c|c|c|c|}
\hline \multirow{2}{*}{$\begin{array}{c}\text { Load } \\
\text { Torque in } \\
\%\end{array}$} & \multicolumn{3}{|c|}{ R-Phase Current THD in \% } \\
\hline & $\begin{array}{l}\text { Conventional } \\
\text { Drive System }\end{array}$ & $\begin{array}{c}\text { Vienna } \\
\text { Rectifier Fed } \\
\text { AC Drive } \\
\text { System }\end{array}$ & $\begin{array}{c}\text { PWM Boost } \\
\text { Rectifier Fed } \\
\text { AC Drive } \\
\text { System }\end{array}$ \\
\hline 100 & 39.55 & 7.68 & 3.44 \\
\hline 75 & 69.98 & 7.55 & 3.28 \\
\hline 50 & 114.89 & 7.35 & 3.32 \\
\hline 25 & 141.19 & 7.42 & 3.05 \\
\hline
\end{tabular}

Table 2 Comparison of AC Drive System with Three Different Front End Converters

The overall comparison of three different front end converter based induction motor drive system is given in Table 2. In this table the R-phase Current THD analysis of three different systems under different load operating conditions. Under all operating conditions the UPF front end converter topologies offers low current THD compared to conventional diode bridge rectifier based system. Further the UPF topology offers constant THD under variable load conditions. Compared to Vienna rectifier the PWM boost rectifier based system the input current THD is very low under all operating conditions.

\section{Conclusion}

In this paper the front-end AC/DC converter of $10 \mathrm{HP}$ induction motor drive system is simulated under three topologies a. conventional AC drive system b. Hysteresis Controller based Vienna rectifier fed AC drive system c. PWM Boost Rectifier fed AC drive system. The input current THD and the corresponding waveform of induction motor drive system has been analyzed and compared under three different FEC topologies. When comparing the harmonic spectrum of these three systems, the PWM Boost Rectifier fed AC drive system achieves the unity power factor at the input supply side, and it produces a THD of $3.93 \%$. Hence it is concluded that the boost PWM rectifier is the best topology for front-end AC/DC converter. By using PWM Boost Rectifier as a front end, it has a following advantages i.e., it produces sinusoidal input current with less THD and maintain unity power factor. The PWM boost rectifier is applied as a front-end converter to control the speed of the Induction motor.

\section{References}

[1] H. Mohan, S. K. Dwivedi and M. Kumar Pathak, "Control of Induction Motor Drives Technological Advancements" 2018 8th IEEE India International Conference on Power Electronics (IICPE), 2018, pp.1-8.

[2] N. Farah et al., "A Novel Self-Tuning Fuzzy Logic Controller Based Induction Motor Drive System: An Experimental Approach" in IEEE Access, vol. 7, pp. 68172-68184, 2019.

[3] C.T. Pan and T. C. Chen, "Modeling and design of an AC to DC converter," in IEEE Transactions on Power Electronics, vol. 8, no. 4, pp. 501-508, Oct. 1993.

[4] M. Rajesh and B. Singh, "Power quality improvement in switched reluctance motor drive using Vienna rectifier," 2012 IEEE Fifth Power India Conference, Murthal, India, 2012, pp. 1-7. 
[5] G. Aiello, M. Cacciato, G. Scarcella, G. Scelba, F. Gennaro and N. Aiello, "RealTimeemulation of a three-phase vienna rectifier with unity power factor operations," 2018 ELEKTRO, 2018, pp. 1-6.

[6] N. C. Foureaux, J. H. Oliveira, F. D. de Oliveira, B. d. J. Cardoso Filho and R. S. de Faria, "Command Generation for Wide-Range Operation of Hysteresis-Controlled Vienna Rectifiers," in IEEE Transactions on Industry Applications, vol. 51, no. 3, pp. 2373-2380.

[7] J. Lee and K. Lee, "Carrier-Based Discontinuous PWM Method for Vienna Rectifiers," in IEEE Transactions on Power Electronics, vol. 30, no. 6, pp. 2896-2900, June 2015

[8] Rohaizan Bin Saher "Three Phase Boost Rectifier Design,"University of Tun Hussein Onn Malaysia”,July 2012.

[9] Vladimir Kati and DusanGraovac," A method of Real Analysis of AC/DC Converter Line Side Harmonics", Electronics and Energetics, vol.10, No.1 (1997).

[10] F. Zare, "Harmonics issues of three-phase diode rectifiers with a small DC link capacitor," 2014 16th International Power Electronics and Motion Control Conference and Exposition, 2014, pp. 912-917.

[11] C-T. Pan and T-Y. Chang, "An Improved Hysteresis Current Controller for Reducing Switching Frequency”, IEEE Trans. Power Electron.,Vol.9,No.1,Jan 1994,pp. 97-104.

[12] Kolar J.W., Drofenik. U., Zach F.C. "Space Vector Based Analysis of the Variation and Control of the Neutral Point Potential of Hysteresis Current Controlled Three-Phase/Switch/Level PWM Rectifier Systems". Proceedings of the International Conference on Power Electronics and Drive Systems, Singapore, Feb.21-24, Vol.1, pp. 22-33 (1995).

[13] S. Jena, B. C. Babu, A. K. Naik and G. Mishra, "Performance improvement of single-phase grid Connected PWM inverter using PI with hysteresis current controller," 2011 International Conference on Energy, Automation and Signal, 2011, pp. 1-5.

[14] Sun, Juan Juan, and Yongdong Li. "Voltage-Oriented Vector Control of Induction Motor: Principle and Performance Improvement." Proceedings of the Power Conversion Conference-Osaka 2002 (Cat. No.02TH8579).

[15] Sylvain LechatSanjuan, "Voltage Oriented Control of Three $\square$ Phase Boost PWM Converters" Chalmers University of Technology, Sweden, 2010.

[16] Mohan N.,Undeland T., Robbins W."Power Electronics, Converters, Applications and Design". Second Edition. John Wiley \& Sons, Inc. USA. 1995. 802p. 